\title{
Education, premise for a workforce reconversion trough a Professional Reinvention
}

\author{
Eugenia Jornea $^{1, *}$, Lucian Lupu-Dima ${ }^{1}$, and Eduard Edelhauser ${ }^{1}$ \\ ${ }^{1}$ University of Petroșani, Universității Street, No. 20, Romania
}

\begin{abstract}
The diversity of resources, made in the 1980-1990 years from Hunedoara County the most industrialized county of Romania. Hunedoara is today one of the most affected by unemployment, poverty and crime. Today Hunedoara is a county that decreased with 140,000 inhabitants in the last 20 years and 75,000 jobs lost, all of these bearing the seal of deindustrialization. An accurate professional framework, could allow the attracting of investors. A first step should be a study of the age and socio professional structure of the population of Hunedoara County, could permit in the next years on focusing to the education of undergraduate and graduate level workforce in the area.
\end{abstract}

\section{Introduction}

Professionals play a key role in meeting health, education, agricultural and water goals: engineers, doctors, nurses, teachers - the whole range of professionals who will be vital to any approach to development. So higher education is not just for people to invest in their own human capital and become part of the elite, but for development to happen, there's going to have to be a lot of professionals trained.[8] Earnings differences are substantial across EU-28 member states even after controlling for price level differences and earnings dispersion. In particular, looking at the 2011 data, inequality in monthly wages is substantially higher in Luxembourg, Netherland or Germany (2800-4000) than in Romania or Bulgaria (330-340). Inequality in income and wages has been increasing in almost all highly industrialized countries over the last decades. This path has been particularly reinforced in the recent crisis, although the impact has not been the same across Europe. If new technologies increase the productivity of highly skilled workers more than for low skilled laborers, wages of highly skilled workers will increase faster.

While technology can boost inequality, better education of laborers can work in the opposite direction.[4] On a local level, Hunedoara county shows a very difficult situation, for example people of Jiu Valley investigated in a study made by a local researcher, reflect a continuous worsening of the quality of life until now of their way of life from material point of view, from $3.7 \%$ of those dissatisfied before 1990 to $42 \%$ between $2000-2009$. [9].

\footnotetext{
* Corresponding author: eduardedelhauser@upet.ro
} 


\section{Analysis of the age structure of the population of Hunedoara County, as well as its professional social profile}

The role of education and training plays a major role in the formation of human capital in supporting economic competitiveness, employment levels of the workforce and not least in personal and professional development. Hunedoara County's population is steadily declining for more than 20 years. Official data presented by the Department of Statistics (Table 1) show that over the past 20 years, Hunedoara county population decreased by $13 \%$, from 544,036 in 1995 to 469,853 in 2016.

Table 1 Population, by age, 1 January (1995-2016), [11]

\begin{tabular}{|c|c|c|c|c|}
\hline \multirow[t]{2}{*}{ Years } & \multirow[t]{2}{*}{ Total } & \multicolumn{3}{|c|}{ By age groups } \\
\hline & & $0-14$ years & $15-59$ years & 60 years and over \\
\hline 1995 & 544036 & 111244 & 349625 & 83167 \\
\hline 2000 & 526797 & 96190 & 339661 & 90946 \\
\hline 2001 & 523662 & 92945 & 338698 & 92019 \\
\hline 2014 & 477675 & 61935 & 310262 & 105478 \\
\hline 2015 & 473635 & 60344 & 305715 & 107576 \\
\hline 2016 & 469853 & 59281 & 301025 & 109547 \\
\hline
\end{tabular}

Table 2 The average number of employees, on activities of national economy (2010-2014), [12]

\begin{tabular}{|l|r|r|r|r|r|}
\hline Years & $\mathbf{2 0 1 0}$ & $\mathbf{2 0 1 1}$ & $\mathbf{2 0 1 2}$ & $\mathbf{2 0 1 3}$ & $\mathbf{2 0 1 4}$ \\
\hline Total County & 108851 & 106870 & 108047 & 106384 & 106877 \\
\hline $\begin{array}{l}\text { Agriculture, forestry and } \\
\text { fishing }\end{array}$ & 2275 & 2236 & 2356 & 2302 & 2908 \\
\hline Industry & 42967 & 41812 & 42755 & 42256 & 41485 \\
\hline Constructions & 7491 & 8195 & 9775 & 8410 & 9392 \\
\hline Wholesale and Retail & 19914 & 20524 & 19740 & 19559 & 19162 \\
\hline Transport and storage & 4970 & 4949 & 4798 & 4117 & 4129 \\
\hline Hotels and restaurants & 2222 & 2145 & 2071 & 2535 & 3596 \\
\hline $\begin{array}{l}\text { Information and } \\
\text { communications }\end{array}$ & 768 & 777 & 730 & 771 & 627 \\
\hline $\begin{array}{l}\text { Financial and insurance } \\
\text { activities }\end{array}$ & 1438 & 1301 & 1270 & 1182 & 1139 \\
\hline Real estate transactions & 321 & 271 & 297 & 344 & 267 \\
\hline $\begin{array}{l}\text { Public Administration } \\
\text { Education }\end{array}$ & 4444 & 3891 & 3726 & 3828 & 3974 \\
\hline Health and social assistance & 8280 & 7861 & 7563 & 7452 & 7354 \\
\hline $\begin{array}{l}\text { Entertainment activities, } \\
\text { cultural and recreation }\end{array}$ & 563 & 626 & 707 & 735 & 907 \\
\hline $\begin{array}{l}\text { Other activities of national } \\
\text { economy }\end{array}$ & 769 & 715 & 630 & 707 & 693 \\
\hline
\end{tabular}

Hunedoara adult population decreases, from 349,625 people in 1995 between 15 and 59 years, to 301,025 people in 2016. The number of children was halved, and the persons over 60 increased by $30 \%$. According to statistics, in 1995, lived in Hunedoara County 111,244 children aged between 0 and 14 years, and in 2016 their number was halved reaching 59,281 . In other words, on average, each year, Hunedoara County had 2,500 children less. Worse is that, while the number of children and young people decreases, the increase is 
only for people over 60 years. In statistics, the number of seniors has increased from 83,167 in 1995 to 109,547 in 2016 (an increase of nearly 30\%).

On the other hand, Hunedoara County employees involved in the activities of the national economy from 2010 to 2014 varies depending on the fields. According to INS statistics (Table 2) we can observe the decrease of employees from 2010 until 2014 in the field of industry with 1,482 , in the field of transport with 841 , in the field of information and communications with 141, in the field of financial activities with 299, in the field of public administration with 470, in the field of education with 598, in the field of health and social care with 926, while an increase was recorded only in the areas such as agriculture with 633 , construction with 1,901, hotels and restaurants with 1,374 and entertainment, cultural and recreational with 344 .

Table 3 The total number of unemployed registered in 2015 and 2016, [2]

\begin{tabular}{|c|c|c|c|c|c|c|c|}
\hline Years & $\begin{array}{c}\text { Total No. } \\
\text { unemployed }\end{array}$ & $\begin{array}{c}\text { of which } \\
\text { women }\end{array}$ & $\begin{array}{c}\text { Total No. } \\
\text { unemployed } \\
\text { paid }\end{array}$ & $\begin{array}{c}\text { Total No. } \\
\text { unpaid } \\
\text { unemployed }\end{array}$ & $\begin{array}{c}\text { Unemployment } \\
\text { rate (\%) }\end{array}$ & $\begin{array}{c}\text { Male } \\
\text { unemployment } \\
\text { rate (\%) }\end{array}$ & $\begin{array}{c}\text { Female } \\
\text { unemployment } \\
\text { rate (\%) }\end{array}$ \\
\hline 2016 & 10789 & 5411 & 4170 & 6619 & 5,79 & 5,42 & 6,21 \\
\hline 2015 & 11131 & 5535 & 3348 & 7738 & 5,88 & 5,42 & 6,43 \\
\hline
\end{tabular}

Before 1989 Hunedoara was considered one of the most industrialized counties. Now, the county is trying to escape from the label of "the jobless county".

In table 3 we can see that in 2016 the unemployment rate was $5.79 \%$, one of the largest in Romania, yet it is gratifying that there is a decrease in the unemployment rate compared to 2015 by $0.09 \%$. According to employment workforce agency statistics, Hunedoara has over 10,789 unemployed. The restructuring of the mining sector increase the unemployment since the area is one mono industrial, and all related activities are related with mining.

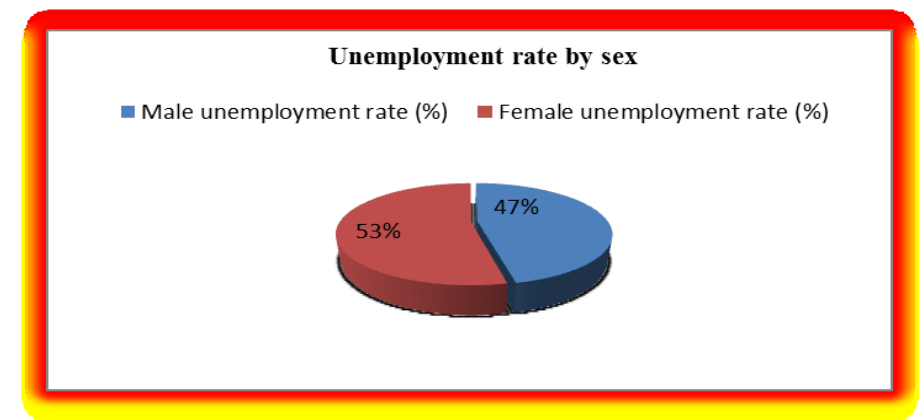

Fig. 1. Unemployment rate by sex 2016 in Hunedoara County

In the figure 1, which refers to unemployment by gender at 31 December 2016, we can see that the female unemployment rate exceeds with $6 \%$ the male unemployment in Hunedoara County.

In figure 2 we have presented the total number of registered unemployed in 2015 and 2016 years, and we can see a decrease from year to year and we can hope that this decrease will occur in the future also, due to increase of labor supply and professional qualification people from Hunedoara County. 


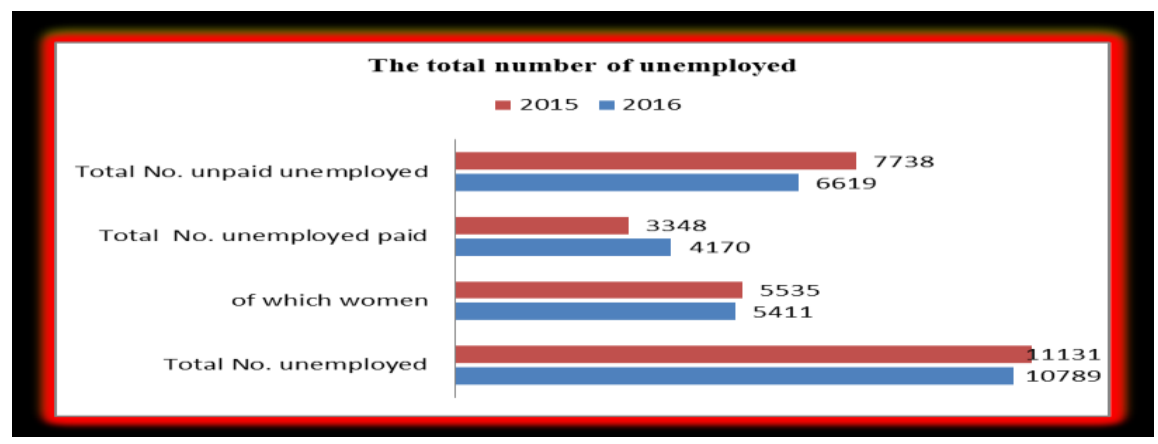

Fig. 2. The total number of unemployed registered in 2015 and 2016 in Hunedoara County

A possible solution of improving the situation in Hunedoara County, could be to restructure the economy by replacing addiction to mining with the creation of a variety of industries and business qualifications.

\section{Statistical analysis of the training programs for the workforce}

Among the most important factors that contribute to a sustainable development of a society, there are economic factors and social factors. By economic, social and political factors, in Hunedoara County the mining sector was held on a distinct position on national level. The financial crisis of the recent years has had an impact on the job market. Many jobs that once brought a stable income disappeared little by little from the market. Employers have changed their requirements and potential employees have to adjust on the fly, so unemployed and some employees had to refocus on the job market. [7]

The main objectives training programs for the workforce are:

- Obtaining a professional qualification

- Adaptation of the employee to the new job or workplace

- Updating knowledge

- Retraining determined by socio-economic restructuring

- Acquisition of advanced knowledge, modern methods and processes needed to achieve professional activities. [10]

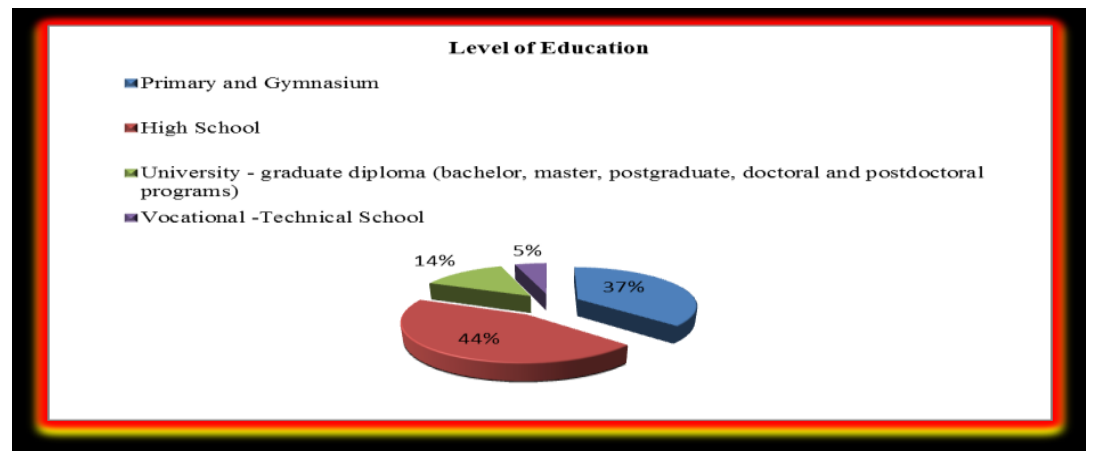

Fig. 3. Classifying the population according to the last level of education of educational institutions graduated in Hunedoara County in 2014 [13]

In terms of training of the workforce, the classification of the active population according to the educational level of the last educational institution graduated in 2014 in Hunedoara County (Figure 3) indicate a high percentage of people who have graduated high school (44\%) followed by those with primary and secondary schools (37\%), university 
education (14\%) and technical and vocational school (5\%). Values are relatively similar to those at the national level.

The high level of population that graduate high school compared to primary, secondary and university education level, raises the question of the need for post-secondary training programs to prepare high school graduates for the labor market. To break the deadlock some people had the courage to begin to make a change and have started business in the wood processing, representing every year a quarter of the county budget, while others are preparing to become specialists in accessing European funds, the so called EU programs.

The management of the National Mine Closures Company (SNÎMVJ) organized training programs for miners. There were over 50 people involved in training programs in the field of expert in accessing European structural and cohesion funds and were 3 classes, the 3 branches mining. Classes were held at Petrila and Uricani Paroşeni. Also miners that are dismissed can follow training programs to learn English or German or to qualify in the profession - craft mechanic.

According to statistics dated 22/02/2017 provided by the Local Agency for Employment Hunedoara, we can observe in figure 4 that most vacancies are for unskilled workers at assembly, fitting parts with 92 positions, after which the top closest followers vendors with 85 positions, truck driver with 33 positions, just as many places available for textile articles assembler, 18 jobs are granted to unskilled worker in the textile industry, 15 jobs for merchandisers, 12 jobs for trade workers and only 4 jobs for security agents. [15]

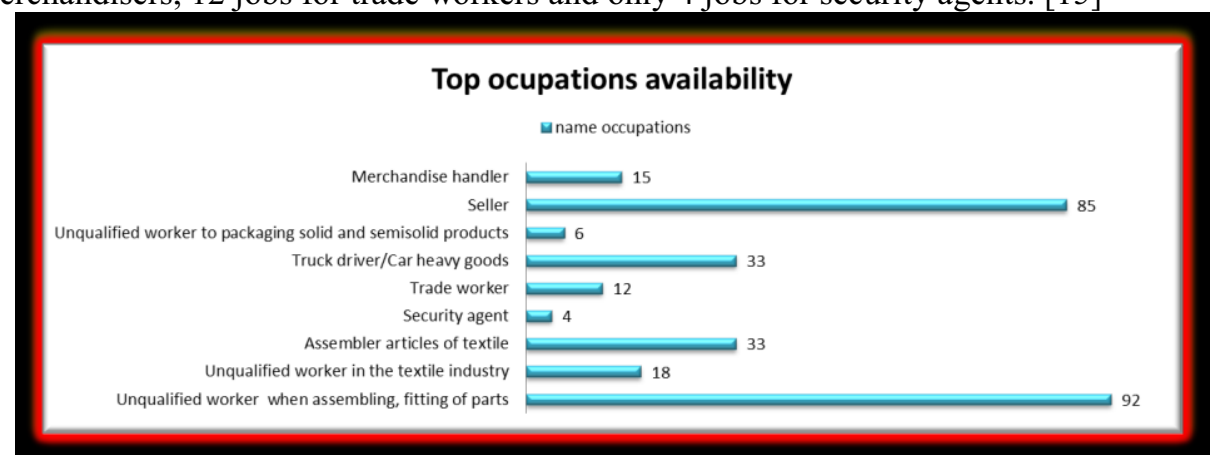

Fig. 4. Top occupations availability in Hunedoara County in 2017

Retraining or reconversion is similar to a reinvention of professional skills. The training programs could be a solution when your last job was eliminated. Of course to recover the situation in Hunedoara County, represent a major problem, besides humane resource development it is needed a strategy for development of the infrastructure of the area as a tourist attraction and diversification of economic activities.

Under the economic context of Romania and especially of the difficult situation the mining areas within Hunedoara and Gorj counties are faced with, the University of Petroşani represent a powerful center for improvement, continuous training and reconversion of the labor force in these counties through an European Founded Project (POSDRU/5.1/S/82/59756) during 2010-2013 years, when we have focused on digital competencies professional training that shall be absolutely necessary in terms of the information society that EU wants to implement. [6] The Project's objective was the increasing the employment rate of the labor force in mono-industrial areas in mining from the Jiu Valley and Oltenia, by attracting young unemployed and long term unemployed, on the labor market, by developing modern and innovative methods for electronic e-learning type of training. [17]. 


\section{Trends in new occupations and professions that might be required in the labor market of Hunedoara County}

Hunedoara County is identified as a single industries or mono industrial county. Highly dependent population of the mining industry, this territory was identified as a fragile area characterized by industrial decline. Performing an analysis of all aspects of the current situation and economic transformations of recent years in Hunedoara County, we can deduced that this county still has chances of recovery and becoming a county with a performance and diversified economy, competitive regionally and why not nationwide. [7]

Hunedoara County must take a series of actions for economic diversification, and support the training in the fields of production systems capable of engaging a large percentage of the workforce. A general objective for the deadlock, as the restructuring of the economy is replacing its dependence on mining as a result of the creation of a variety of industries and business qualifications. In this regard, metallurgy and textiles are already directions viable, also automotive and tourism and IT sector shows high growth potential, while being regional areas of interest. Another means of achieving the overall objective is to encourage private sector development, including actions such as creating a favorable business environment by focusing on SMEs. According to the Post-privatized Foundation Report on SME sector in Romania in 2013, specified that the share of SMEs of all registered companies is $99.7 \%$ and the number of employees of SMEs in Romania is 65.9 $\%$ of total employment in enterprises, we can say that the future of graduate job may be largely an SME. [3]

Hunedoara County loses chance for investments because it is not prepared infrastructural. Business support infrastructure is unevenly distributed in the county and its absence is highlighted especially in areas with reconversion problems. It is necessary to focus attention on the creation and investments in business incubators and the establishment of business parks. At the moment, there are registered in Hunedoara County 3 Industrial Parks - Hunedoara Industrial Park, Business Incubator Simeria and Călan Industrial Park (including business incubator) offering new opportunities to attract and retain investors in the county.

Another objective of the development strategy of Hunedoara County would support the development of tourism as a new sector of economic activity. Hunedoara County is one of the regions in Romania with most tourist spots, but unfortunately this area is not exploited. There is a lack of an unified management of protected areas that allow the practice of tourism in these areas, lack management knowledge, law and ignorance of foreign languages by those involved in networks of rural tourism so alpine areas are used to a minimum potential, lack of information and tourist maps, lack of access roads to tourist attractions, lacking specialized human resources in the field, lack of development organizations tourism. Developing a well thought out and implemented management would solve these problems, but of course with raising capital.

To develop a management, a very important current and future has the IT field. The European Commission launched a coalition for skills and jobs in the digital sector for career development and improving daily life.

The stated purpose is to reduce the existing digital skills shortages at all levels, from highly specialized IT to those who need all citizens to live, work and participate in the digital economy and society. The lack of digital skills are an obstacle to innovation and growth. In Europe, in all sectors remain vacant jobs because of the number of people who cannot use a computer. European Commission stated that 2020 to 750,000 jobs in IT will not be occupied because of this. A situation which is recorded in the context of an unemployment rate of nearly 20 percent among young Europeans aged between 15 and 24 years. More generally, almost 45 percent of Europeans have only basic digital skills. The 
goal is that by 2020 national coalitions exist in all Member States because until the same year, 2020, one million young people are unemployed to undertake training to fill the vacancies in the digital sector.

It would also be funded retraining the workforce with practical measures to support SMEs face particular challenges in terms of attracting and retaining talent in the digital domain. The plan is a modernization of education, to give all students and teachers the opportunity to use digital tools and materials in teaching and learning. [16]

\section{Conclusion}

Hunedoara County is now branded as a single industries county and having an industrial decline in recent years, so could be called a fragile area. In this paper based on economic, social and educational information, we can conclude that the recovery of Hunedoara County could be possible by developing and implementing development strategies, which should be on medium and long term.

The transition to a sustained economy must support, on the one hand, on retraining the workforce, and on the other hand, on attracting new investment. Therefore, it is necessary that county and local authorities work together to develop a joint plan of economic reorientation. Hunedoara County loses chance for investments because it is not prepared infrastructural. Business support infrastructure is unevenly distributed in the county and its absence is highlighted especially in areas with reconversion problems. It is necessary to draw attention to investment and on training the population Hunedoara on various fields in accordance with market demand jobs. $T$

he strengths of Hunedoara county, which would help change the economic course would draw attention to the development of tourism as a new sector of economic activity, focusing investments on business incubators and business parks, encouraging private sector-development of SMEs, and on course to pay particular attention to IT, which is one current and future opportunity.

\section{References}

1. $* * *$ http://www.ajofmhd.ro

2. $* * *$ http://www.anofm.ro/statistica

3. $* * *$ http://webcache.googleusercontent.com/search? $\mathrm{q}=$ cache:ruaY9dLak0wJ:mcr.doingbusiness.r o/uploads/51c2bb33b342cSINTEZA_Raport\%2520IMM\%2520-

$\% 25202013 . \mathrm{docx}+\& \mathrm{~cd}=1 \& \mathrm{hl}=\mathrm{ro} \& \mathrm{ct}=\mathrm{clnk} \& \mathrm{gl}=\mathrm{ro}$

4. C. Dreger, E. López-Bazo, Wage and Income Inequality in the European Union, IP/A/EMPL/2013, (Available at: http://www.europarl.europa.eu/studies, 2015)

5. E. Edelhauser E., A. Ionica, M. Leba, Transformations in Business \& Economics, 13 (32B), $742-$ 759, (2014)

6. E. Edelhauser, L. Lupu-Dima, A. Ionică, M. Leba, Annals of the University of Petrosani, Economics, XII (3), 57-66, (Universitas Publishing House, Available at: http://www.upet.ro/annals/economics/2012.php, 2012)

7. E. Edelhauser, Sisteme informatice în managementul resurselor umane, (Universitas Publishing House, 2011).

8. G. Kruss, S. McGrath, I. Petersen, M. Gastrow, International Journal of Educational Development, 43, 22-31,(Available at: https://www.elsevier.com/atlas/story/people/highereducation-is-key-to-economic-development , 2015)

9. R. Pleșa, Annals of the University of Petroşani, Economics, XII (3), 187-196, (Available at: http://www.upet.ro/annals/economics/pdf/2012/part3/Plesa.pdf, 2012).

10. $* * *$ http://www.gov.ro

11. $* * *$ http://www.hunedoara.insse.ro/main.php?lang=fr\&pageid=409

12. $* * * \mathrm{http}: / / \mathrm{www} \cdot$ hunedoara.insse.ro/main.php?lang=fr\&pageid $=479$ 
13. $* * *$ http://statistici.insse.ro/shop/

14. $* * * \mathrm{http}: / /$ date.edu.ro

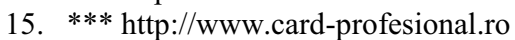

16. $* * * \mathrm{http}: / /$ www.romania-

actualitati.ro/coalitie_pentru_competente_si_locuri_de_munca_in_sectorul_digital-97031

17. $* * * \mathrm{http}: / /$ www.upet.ro/proiecte/ 